Bangladesh J. Plant Taxon. 24(1): 9-12, 2017 (June)

(C) 2017 Bangladesh Association of Plant Taxonomists

\title{
A NEW SPECIES OF LEIORREUMA (ASCOMYCOTA, OSTROPALES) FROM GREAT NICOBAR ISLAND, INDIA
}

\author{
Pushri Singh, T.A.M. JagAdEESH RAM ${ }^{1}$ AND K.P. SinGH ${ }^{2}$ \\ Botanical Survey of India, Central Regional Centre, 10-Chatham Lines, \\ Allahabad- 211 002, India.
}

Keywords: Ascomycota; Lichenized fungi; New species; Taxonomy; Sundaland.

\begin{abstract}
Leiorreuma nicobarense Pushpi Singh, Jagadeesh and Kr. P. Singh, a new species from Great Nicobar Island, India is described and illustrated. It is characterized by its sessile lirellae with widely exposed densely whitish pruinose disc, inspersed hymenium, 8-spored asci with 6-locular ascospores and presence of stictic, constictic and hypostictic acids. Key to species occurring in India is provided.
\end{abstract}

Introduction

\section{Introduction}

Great Nicobar Island, the largest island of the Nicobar group, about $145 \mathrm{~km}$ north of Sumatra and about 1,300 km south-east of the Indian mainland covering a geographical area of $1044 \mathrm{sq} . \mathrm{km}$ and a part of the Sundaland biodiversity hotspot (Mittermeier et al., 2005) is situated between $6.45^{\circ} \mathrm{N}$ and $7.15^{\circ} \mathrm{N}, 93.37^{\circ} \mathrm{E}$ and $93.56^{\circ} \mathrm{E}$ and forms the southernmost point of India. It offers congenial habitats for the luxuriant and rich growth of crustose lichen biota because of the tropical evergreen coastal and mangrove forests, always in contact with moisture laden sea winds and high annual rain fall (over $3000-3500 \mathrm{~mm}$ ) and humidity. While studying some collections of lichens made by Botanical Survey of India team from the island under revisionary studies of Indian Graphidiod Graphidaceae, an interesting species of Leiorreuma Eschw. as new to science was discovered. The genus is characterized by its immersed to sessile lirellae with opened disc, basally well-developed laterally often thin carbonized exciple, inspersed hymenium with brown, transversely septate or muriform ascospores and presence of stictic, hypostictic or nornotatic acids or absence of lichen compounds. The genus is represented by c. 18 species (Staiger, 2002; Archer, 2006; Lendemer, 2008; Lendemer et al., 2009; Moon et al., 2008; Dubey et al., 2010; Poengsungnoen et al., 2014; Wang et al., 2015) in the world, of which 3 species (Singh and Sinha, 2010; Dubey et al. 2010) occur in India. In the present communication, a new species Leiorreuma nicobarense is described together with a key of all species known so far, from Indian territories to facilitate their identification.

\section{Material and Methods}

Specimens collected from Nicobar Islands, deposited in PBL herbarium were examined morphologically, anatomically and chemically. Morphological characters of thallus, reproductive structures, colour, size and shapes were examined under stereomicroscope (NIKON SMZ 1500). Thin hand-cut sections of thalli and ascomata were mounted in water and $\mathrm{KOH}$ and examined under a compound microscope (Nikon Eclipse 50i). All anatomical measurements were made in water mounts. Ascospores were stained with Lugol's solution to check the amyloid reaction.

${ }^{1}$ Botanical Survey of India, Andaman and Nicobar Regional Centre, Port Blair-744 102, Andaman and Nicobar Islands, India.

2Corresponding author. Email: krishna.p.singh@gmail.com

DOI: http://dx.doi.org/10.3329/bjpt.v24i1.33000 
Secondary metabolites were identified by thin-layer chromatography (TLC) following standard procedures (Orange et al., 2001).

\section{Results}

Leiorreuma nicobarense Pushpi Singh, Jagadeesh and Kr. P. Singh sp. nov.

(Fig. 1A-D) Myco Bank no. : MB 820636

Diagnosis: The new species Leiorreuma nicobarense differs from $L$. exaltatum (Mont. \& Bosch) Staiger and L. taiwanense M. Nakan., Kashiw. \& K.H. Moon in chemistry, from $L$. melanostalazans in sessile lirellae, constantly 6-locular ascospores and presence of constictic and hypostictic acids.

Type: India, Andaman and Nicobar Islands, Great Nicobar Island, North South road, Sastri Nagar, 6 $48^{\prime} 39.6^{\prime \prime} \mathrm{N}$ and 93 53'27.7" E, alt. $15 \mathrm{~m}$, on the bark of Artocarpous lakoocha, 09 February 2014, K. P. Singh and T.A.M. Jagadeesh Ram 2978 (Holotype: PBL).

Thallus crustose, corticolous, irregular, pale fawn to greyish fawn, continuous, glossy, smooth to wrinkled, 6-7 $\mathrm{cm}$ across, $75-100 \mu \mathrm{m}$ thick; prothallus indistinct; photobiont green, Trentepohlia, algal cells $8-10 \mu \mathrm{m}$ across.

Ascomata lirelliform, numerous, sessile, elongate, sparsely branched, straight to irregularly curved or flexuous, $2-8 \mathrm{~mm}$ long, $0.3-0.7(-1) \mathrm{mm}$ broad, rounded at the ends, covered laterally by thick thalline margin; disc widely exposed, concave to flattened, brownish-black, heavily whitish pruinose; labia divergent, entire; exciple completely carbonized, basally 100-180 $\mu \mathrm{m}$ thick, lateral exciple typically surrounded by large calcium oxalate crystals; epihymenium dark brown, granulose, 9-14 $\mu \mathrm{m}$ thick; hymenium hyaline, inspersed, 80-130 $\mu \mathrm{m}$ high, I-; paraphyses simple, c. $1.5 \mu \mathrm{m}$ thick; asci 8-spored, cylindrical, 64-100 $\times 10-20 \mu \mathrm{m}$; ascospores brown, oblong to fusiform, transversely septate with constantly 6-locular (mature ones), 18-25 $\times 6-7.2 \mu \mathrm{m}$ $(\mathrm{n}=25)$, I+ reddish-brown.

Etymology: The specific epithet refers to its inventory from the Nicobar Island.

Chemistry: Thallus $\mathrm{K}+$ yellow, $\mathrm{C}-, \mathrm{KC}-, \mathrm{P}-$ and UV-; TLC: constictic, stictic, (major), hypostictic (trace) acids.

Distribution and habitat: Leiorreuma nicobarense is known so far, from habitation area seashore in Great Nicobar Island of the Nicobar Islands, part of the Sundaland biodiversity hotspot. It grows in shady and open place on the trunk of cultivated Artocarpous lakoocha and can be spotted easily by its large, sessile and broad lirellae with whitish pruinose disc.

Notes: The new species is characterized by its distinct sessile lirellae, covered laterally by thick thalline margin with widely exposed densely whitish pruinose disc; inspersed hymenium; 8spored asci; ascospores constantly 6-locular (18-25 $\mu \mathrm{m}$ long) and presence of constictic, stictic and hypostictic acids. In morphology and anatomy, it closely resembles Leiorreuma taiwanense M. Nakan., Kashiw. \& K.H. Moon which contains hypoprotocetraric and 4'-O-demethyl-notatic acids (Moon et al., 2008). Morphologically, it also closely resembles Leiorreuma exaltatum (Mont. \& Bosch) Staiger and L. subpatellulum Dubey, Upreti \& Nayaka but later species differ in having 6-8-locular, 20-34 $\mu \mathrm{m}$ long (Staiger, 2002) and 7-13-locular, 40-46 $\mu \mathrm{m}$ long (Dubey et al., 2010) ascospores respectively and absence of lichen substances. In chemistry, it also closely resembles Leiorreuma melanostalazans (Leight.) A.W. Archer, which contains immersed lirellae, epruinose to finely pruinose disc, 8-9-locular, larger $(25-37 \times 8-10 \mu \mathrm{m})$ ascospores and absence of constictic and hypostictic acids (Archer, 2006). 

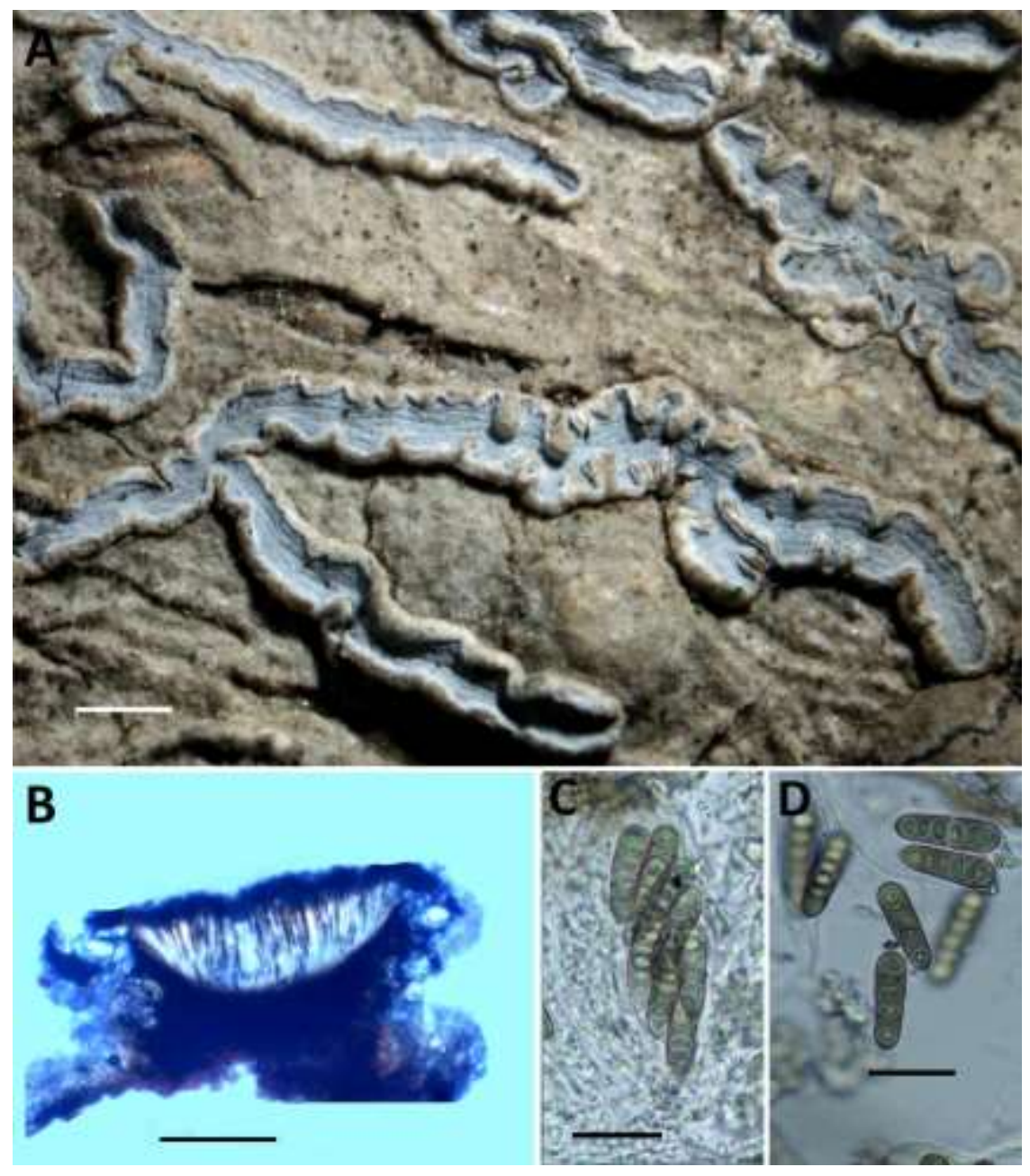

Fig. 1. A-D. Leiorreuma nicobarense. A. Habit; B. Cross section of apothecium, C-D. Ascospores. Scale bars: $A=1 \mathrm{~mm} ; \mathrm{B}=200 \mu \mathrm{m} ; \mathrm{C}-\mathrm{D}=20 \mu \mathrm{m}$.

\section{Key to the Indian species of Leiorreuma}

1. Ascospores 6-locular; lirellae sessile; constictic, stictic and hypostictic acids present; ascospores 18-25 × 6-7.2 $\mu \mathrm{m}$

L. nicobarense

- Ascospores more than 6-locular

2

2. Stictic acid present; lirellae immersed in the thallus; ascospores 8-9locular, 25-37 × 8-10 $\mu \mathrm{m}$

L. melanostalazans

- Lichen substances absent; lirellae erumpent to prominent

3

3. Ascospores 6-8 locular, 20-34 × 6-9 $\mu \mathrm{m}$

L. exaltatum

- Ascospores 7-13 locular, 40-46 × 8-10 $\mu \mathrm{m}$

L. subpatellulum 


\section{Acknowledgements}

The authors are thankful to the Director, Botanical Survey of India, Kolkata for encouragement and to Head of Office, Botanical Survey of India, Central Regional Centre, Allahabad and Botanical Survey of India Andaman and Nicobar Regional Centre, Port Blair for facilities. One of the authors (PS) is thankful to the authorities of Botanical Survey of India, for financial assistance under the 'Flora of India Project'.

\section{References}

Archer, A. W. 2006. The lichen family Graphidaceae in Australia. Biblioth. Lichenol. 94: 1-191.

Dubey, U., Upreti, D.K. and Nayaka, S. 2010. A new species of Leiorreuma Eschw. from India. Lichenologist 42: 711-713.

Lendemer, J.C. 2008. Studies in Lichens and Lichenicolous Fungi: notes on some taxa from eastern North America. Mycotaxon. 104: 325-329.

Lendemer, J.C., Kocourkova, J. and Knudsen, K. 2009. Studies in Lichens and Lichenicolous Fungi: more notes on taxa from North America. Mycotaxon. 110: 373-378.

Mittermeier, R.A., Gil P.R., Hoffman M., Pilgrim J., Brooks T., Mittermeier C.G., Lamoreux J. and de Fonseca G.A.B. (eds). 2005. Hotspots revisited: Earth's biologically richest and most endangered terrestrial ecoregions. Mexico: CEMEX, 392 pp.

Moon, K.H., Nakanishi, M. and Kashiwadani, H. 2008. Notes on species of Graphidaceae (Ascomycotina) Eastern Asia with three new species. Mem. Natl. Sci. Mus. (Tokyo) 45: 85-91.

Orange, A., James, P.W. and White, F.J. 2001. Microchemical methods for the identification of lichens. British Lichen Society, UK, pp.1-101.

Poengsungnoen, V., Manoch, L. Mongkolsuk, P. and Kalb, K. 2014. New species of Graphidaceae from Loei Province, Thailand. Phytotaxa 189: 255-267.

Singh, K.P. and Sinha G.P.. 2010. Indian lichens: Annotated Checklist. Kolkata: Botanical Survey of India, $571 \mathrm{pp}$.

Staiger, B. 2002. Die Flechtenfamilie Graphidaceae: Studien in Richtung einer naturlicheren Gliederung. Biblioth. Lichenol. 85: 1-526.

Wang, X.H , Xu, L.L. and Jia, Z.F. 2015. The lichen genus Leiorreuma in China. Mycotaxon. 130: 247-251. 